\title{
Characteristics and Sensory Analysis of Ketchup and Sauce Products from "Bibisan" Fish Hydrolyzate
}

\author{
Yuli Witono $^{1, *}$, Wiwik Siti Windrati ${ }^{1}$, Iwan Taruna ${ }^{2}$, Asmak Afriliana ${ }^{1}$, Ahib Assadam ${ }^{1}$ \\ ${ }^{1}$ Department of Agricultural Product Technology, Faculty of Agriculture Technology, University of Jember, Jl. Kalimantan IJember, \\ East Java, Indonesia \\ ${ }^{2}$ Department of Agricultural Engineering, Faculty of Agriculture Technology, University of Jember, Jl. Kalimantan IJember, East Java, \\ Indonesia \\ *Corresponding author: yuliwitono.ftp@unej.ac.id
}

Received November 08, 2014; Revised November 30, 2014; Accepted December 03, 2014

\begin{abstract}
Bibisan" fish can be developed into a food flavor using enzymatic hydrolysis. The combination of "Biduri" protease and papain can shorten the time of hydrolysis. Bibisan fish hydrolyzate can be made derived products like the fish sauce and fish ketchup. Proximate analysis of fish sauce and ketchup observedincluding moisture content (72-74\%), protein (9-10\%), fat (9.15 to 16.3\%), and ash (5.81 to 9.90\%). Theabsorbance average value of Maillarddegree obtained from experiment then result of inferior fish sauce ranged from 0.432 to 0.463 while the fish ketchup ranged from 0228 to 0.281 . Fish sauce color is lighter (light brown) instead of fish ketchup. Viscosity of fish sauce (14.86 to $18.78 \mathrm{mp}$ ) were also higher than fish ketchup (10.81 -14.80 mp). The highest amino acid inof bibisan fish hydrolyzate was glutamic acid that range from $8.76 \%-10.17 \%$; while the lowest AA was histidine (1.12 to $1.22 \%)$. The sensory evaluation of fish sauce and ketchup reveals that the products have a good sensory quality and overall acceptability.
\end{abstract}

Keywords: "Bibisan" hydrolyzate of fish, biduri protease, papain, fish sauce, fish ketchup, sensory attributes

Cite This Article: Yuli Witono, Wiwik Siti Windrati, Iwan Taruna, Asmak Afriliana, and Ahib Assadam, "Characteristics and Sensory Analysis of Ketchup and Sauce Products from "Bibisan" Fish Hydrolyzate." American Journal of Food Science and Technology, vol. 2, no. 6 (2014): 203-208. doi: 10.12691/ajfst-2-6-6.

\section{Introduction}

Fish bibisan is inferior fish source from the Indonesian seas, especially in Madura seas. At harvest season, these inferior fish is very abundant and has not been widely used as an industrial raw material. Therefore, it needs to be explored further the potential of the indigenous flavor of local natural materials in Indonesia. Fish bibisan can be developed into a food flavor to reduce dependency of imported food ingredient in Indonesia.

Production technology engineered of flavor enhancers can be developed through hydrolysis technique. Enzymatic hydrolysis is the safest method of choice and is more profitable than chemical hydrolysis, because hydrolysis enzymatically generated free amino acids and variety of short chain peptides. The product has a wider range of uses in the food industry [1]. Protease enzyme derived frombiduri plant (Calotropis gigantea) is also local natural source from Indonesia. Results of previous studies have shown that extracts of the plant Biduri either from the sap, stems and leaves great potential as a source of protease enzyme [2,3,4,5]. Characterization of the protease Biduri, based on its specificity indicates included inexopeptidase [4] which is very suitable for production protein hydrolysates as flavor enhancer. Modification of the enzymatic hydrolysis between Biduri protease and synergism with the papain was found can improve the performance of proteases Biduri to hydrolyze substrates in inferior fish [6].

Derivative products that can be developed from fishbibisan hydrolyzate is fish sauce and ketchup. Both of these products can evoke 'umami' (savory flavor) and as a source of flavor. Fish sauce is a fermented product that has a brown liquid and commonly usedin Asian countries. These products are used for a variety of fast food, because it can improve the flavor and increase nutritional value. However, consumption of sauce and savory ketchup from fish are rarely found in Japan and Europe because of the smell of fish was over powering. In Southeast Asia, fish sauce and fish ketchup is not only popular as a flavoring, but in some areas are used as well as the main protein source for diet and become the household [7].

According Fukami [8], process of the hydrolysis treatment resulted unpleasant odor and taste. These characteristics significantly affect consumer acceptance of fish sauce and fish ketchup. Sensory studies on bibisan fish hydrolyzate derivative products are limited. The purpose of this research is to study the characteristics and sensory acceptance of fish sauce and fish ketchup products from bibisanfish hydrolyzate.

\section{Materials and Methods}




\subsection{Materials}

Raw materials used in this experiment is bibisan fish (Apogon albimaculosus) obtained from the TalangoVillage, Sumenep, Madura, Biduri protease and papain, sucrose, cysteine, salt, refined sugar, CMC, brown sugar, deaf, extract of fermented cassava, maltodextrin. Chemicals used were distilled water, selenium, $\mathrm{H}_{2} \mathrm{SO}_{4}$, boric acid, nhexane, $2 \mathrm{~N} \mathrm{NaOH}, 0.1 \mathrm{~N} \mathrm{HCl}$, phosphate buffer $\mathrm{pH} 7$, Mix-Lowry $\left(\mathrm{Na}_{2} \mathrm{CO}_{3}\right.$ anhydrous CuSO4) Follin, tyrosine standard, BSA standardsand $20 \mathrm{mLof} 1 \mathrm{M} \mathrm{KCl}$.

Tools used include: stainless steel blender, centrifuge Yenaco YC-1180 models and the tube, Roy Spectronic 21 D Melton and cuvet, Jen Way-type 3320 of $\mathrm{pH}$ meter (Germany), magnetic stirer Stuart Scientific and stone stirer, vortex Thermolynetype 16700, refrigerator, stop watch, oswald viscometer, HPLC, waterbath GFL 1083, Ohaus analytical balance, electric heating Gerhardt, spatula, vacuum oven, vortex Maxi Max Type 16700, 80 mesh of sieve, distillates, biuret, film bottles, then equipment for sensory analysis such as trays, plastic cups, spoons, testing form.

\subsection{Methods}

\subsubsection{Production of Inferior Bibisan Fish Hydrolyzate}

Bibisan was filled to separate between the fish and the skin. Then the fish meat was steamed for 10 minutes and then crushed to produced suspension. After that $\mathrm{pH}$ adjustment was carried out using $2 \mathrm{NNaOH}$. Then added protease Biduri $(\mathrm{B})$ and papain $(\mathrm{P})$ mixture by ratio $70 \mathrm{~B}$ : 30P, 50B: 50P, 30B: 70P. Hydrolysis by $55^{\circ} \mathrm{C}$ for 90 minutes. After that inactivation of the enzyme by $100^{\circ} \mathrm{C}$ for 10 minutes, so it produced wet hydrolyzate. Then dried $60^{\circ} \mathrm{C}$ for 18 hours and pulverized to produced dried fish meat hydrolyzate.

\subsubsection{Fish Sauce Production}

The process of making fish sauce is shown in Figure 1. Dried hydrolyzate ofbibisan fish meat was dissolved with $30 \mathrm{ml}$ of water in a glass beaker. Then the solution mixture (30\% sugar, $10 \%$ glucose and $1.5 \%$ deaf) was added. Then the solution was kept to boil for $5 \mathrm{~min}$ and it was filtered. Then added 1\% maltodextrin and 1\% CMC, boiled for 30 minutes. Last, it was did filtering to separate the sauce from the dregs.

\subsubsection{Fish Ketchup Production}

10 grams of dried hydrolyzate diluted with $40 \mathrm{ml}$ of water in a glass beaker. Then added the mixture solution of (30\% sugar, $10 \%$ glucose, $5 \%$ extract of fermented cassava, and1\%deaf) in boiling conditions. Then did filtering to separate the pulp. After that it was did mixing with thickeners such as $30 \%$ brown sugar and $10 \%$ of caramel at the boiling time. Boiled until boiling for 30 minutes. Last, it was did filtration again to separate pulp then to produce fish ketchup.

\subsection{Chemical Analysis}

Protein hydrolyzate was analyzed in three replicates and then the average value was recorded. The determinations of the crude protein, fat, and ash were carried out at the Chemistry and Bio Chemistry
Laboratory, Agricultural Product Technology Department, Agricultural Technology Faculty, University of Jember, Indonesia. The chemical compositions of all samples were determined by the following AOACprocedures [9]; crude fat, by Soxhlet extraction with benzene; crude ash, by Incineration in a muffle furnace at $500^{\circ} \mathrm{C}$ for 8 hours; crude protein ( $\mathrm{N} \times 6: 25$ ), by the Kjedahl methods. Rancidity levels were determined using the method using TBA [10]. Maillard products determined by absorbance [11].

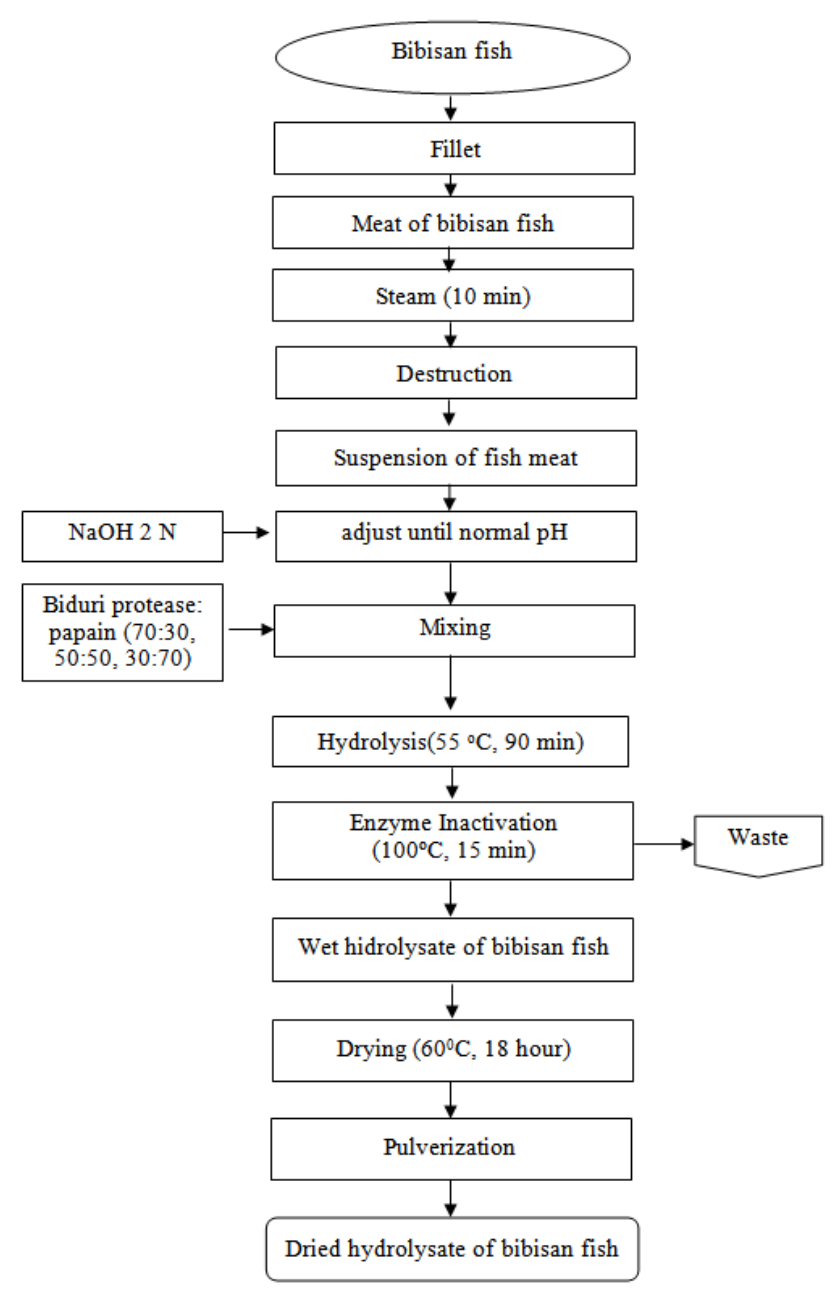

Figure 1. Flowchart of Protein Hydrolysis From Bibisan Fish

\subsection{Physical Analysis}

Color analysis was determined using the color reader. Measurement of viscosity using a oswald viscometer. $2 \mathrm{ml}$ of sample mixed with $2 \mathrm{ml}$ of distilled water. Then taken $65 \mu \mathrm{l}$ of mixture and put into the oswald viscometer using a micropipette by closing one of the lid ofoswald viscometer. After the mixture was inserted, open the lid of viscometer and calculate material flow time using a stopwatch (measured in seconds), and the magnitude of the viscosity was calculated by the following formula:

$\mathrm{t} 1 \times \mathrm{t} 2 \times \eta 2=\eta 1$

where:

$\mathrm{t} 1$ = flowtime of water (2.12 seconds)

$\mathrm{t} 2$ = flow time of materials

$\eta 1=$ viscosity of water $\left(827.681 \times 10^{-5}\right) \mathrm{Pa}$

$\eta 2=$ viscosity of materials

viscosity obtained is converted to units of milipoise (mp) with the formula: 
$\eta 2(\mathrm{mp})=\eta 2(\mathrm{~Pa}) \times \mathrm{t} 2$ (seconds) $\times 100$

\subsection{Amino Acid Profile}

Amino acid determinations were carried out at Saraswati Indo Genetech Laboratory Ltd., Bogor, Indonesia. Amino acids in the freeze-dried samples after acid hydrolysis were analysed in $6 \mathrm{~N} \mathrm{HCl}$ for $22 \mathrm{~h}$ at $110^{\circ} \mathrm{C}$ in glass tubes under nitrogen. Heating is done to Accelerate the hydrolysis reaction. Chromatography analysis was carried out using HPLC device, equipped with ion-exchange column and a UV-Vis detector; and post-column derivatization with ninhydrin was carried out.

\subsection{Sensory Analysis}

A Hedonic scale of 1-5 with twenty-trained panelists were employed to evaluate the sensory characteristics of fish sauce and savory salt on appearance, color, aroma, taste, texture, mouthfeel, and overall acceptability [12]. The 5-point Hedonic scale was rated as $5=$ extremely like, 4 = like, 3 = moderately, 2 = dislike, 1 = strongly dislike. The individual scores were averaged and analyzed.

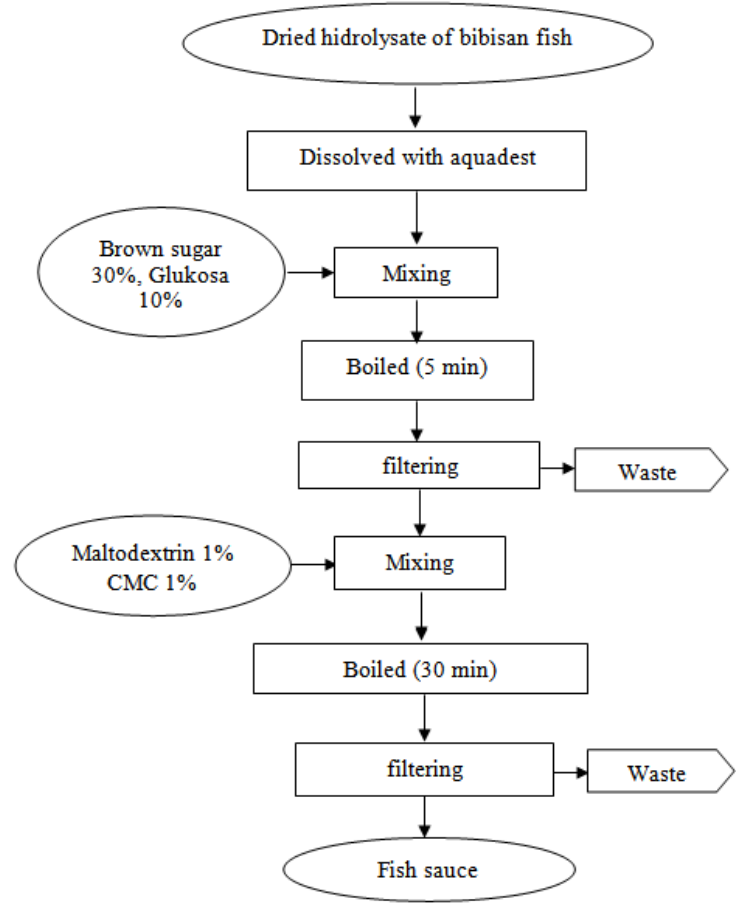

Figure 2. Production of Fish Sauce

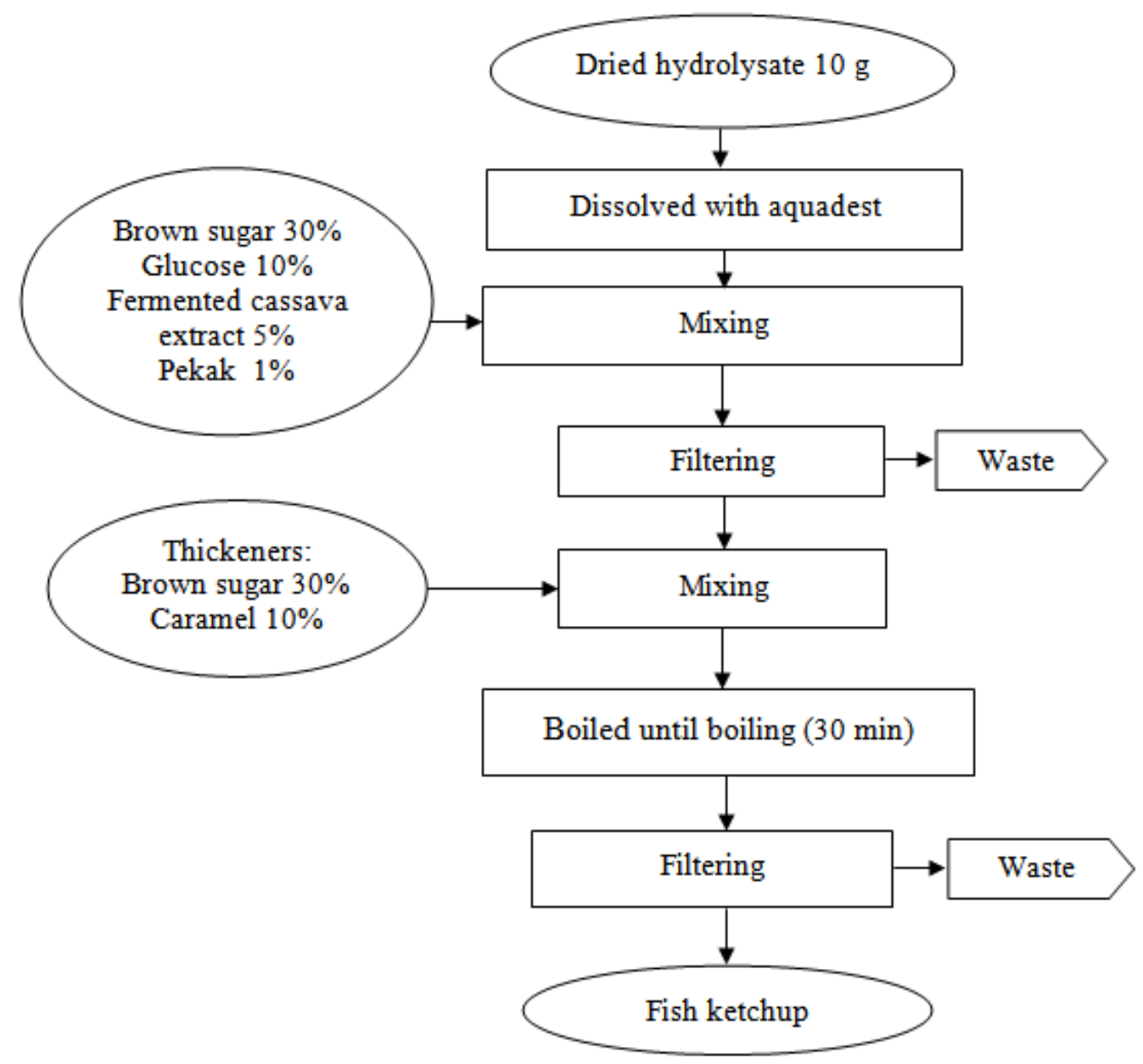

Figure 3. Production of Fish Ketchup

\section{Results And Discussion}

\subsection{Proximate Analysis}

Proximate analysis of fish sauce and ketchup observed including moisture content, protein, fat, and ash. The results were expressed as a mean of triplicate and represented in Table 1. 
Tabel 1. Proximate Composition of Fish Sauce and Ketchup using Biduri and Papain enzyme

\begin{tabular}{cccc}
\hline $\begin{array}{l}\text { Ratio between } \\
\text { biduri: papain }\end{array}$ & \multicolumn{2}{c}{ Fish Sauce } \\
\cline { 2 - 4 } & $\begin{array}{c}\text { Moisture } \\
\text { Content (\%) }\end{array}$ & $\begin{array}{c}\text { Ash } \\
\text { Content (\%) }\end{array}$ & $\begin{array}{c}\text { Pat } \\
\text { Content (\%) }\end{array}$ \\
\hline 30 B : 70 P & $74.82 \pm 0.21$ & $6.96 \pm 0,01$ & $16.3 \pm 0,28$ \\
50 B : 50 P & $74.80 \pm 0.05$ & $7.08 \pm 0,11$ & $15.23 \pm 0,19$ \\
70 B : 30 P & $72.65 \pm 0.04$ & $9.90 \pm 0,03$ & $15.20 \pm 0,02$ \\
30 B : 70 P & & Fish Ketchup (\%) & $12,80 \pm 0,01$ \\
50 B : 50 P & $83.35 \pm 0,28$ & $5.81 \pm 0,12$ & $10.25 \pm 0,04$ \\
70 B : 30 P & $82.27 \pm 0,20$ & $6.45 \pm 0,03$ & $7,35 \pm 0,02$ \\
\hline
\end{tabular}

Data were presented as proximate analysis by AOAC methode (2005), means \pm SD (standard deviation), triplicate ( $\mathrm{n}=3$ ).

Water content of fish ketchup is higher than the fish between reducing sugars with primary amine groups. sauce. The water content of fish ketchup ranges from 81$83 \%$, while the water content of fish sauce ranges from 72-74\%. Fat content in the fish sauce significantly higher than fish ketchup. This is may also have been partly from the difference in the moisture and fat ratio in the raw material. An inverse relationship between moisture and lipid content has been observed in capelin [13] (Bragado et al., 2002). The results obtained in this study revealed that in agreement with previously reported values by Bersamin and Napugan [14 ]who found 62-74\% moisture content in commercially produced Patis (fish sauce). The protein content of fish sauce is $9-10 \%$, the number is higher than fish ketchup. These results are consistent with previous research, Lopetcharat and Park reported 15.7 g N / l of total protein for Pacific whiting [15].

\subsection{Maillard Product}

Absorbancevalue of Maillardfor fish sauce and fish ketchupis shown in Figure 4. Average value ofMaillard degreeabsorbance obtained from study of inferiorityfish sauce bythe addition of thickener variation ranging from 0.432 to 0.463 . The addition of CMC thickeners can enhance hazel inflicted on the fish sauce. This is because CMC can trap posed a brownish red color of brown sugar, glucose and fermented cassava water so that the Maillard reaction occurs [16].

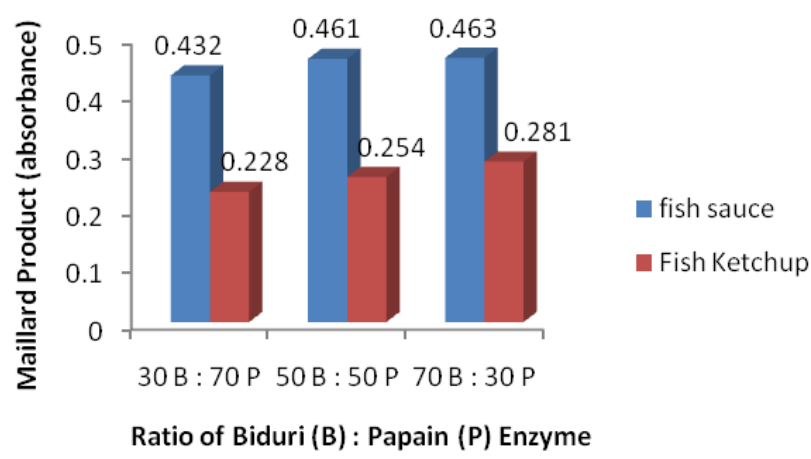

Figure 4. Maillard Value Absorbance of Fish Sauce and Ketchup

The observation of the degree of Maillard in fish ketchup with the addition of sugar treatment $30 \%$ red and $10 \%$ caramel ranged from 0228 to 0.281 from the absorbance at a wavelength of $420 \mathrm{~nm}$. Maillard reaction in ketchup products can be seen from the intensity of the color formation in the product. This can be seen in the UV-vis absorption or wavelength in the ketchup. Maximal uptake occurs on all products in the range of $400-420 \mathrm{~nm}$ wavelength, which is the characteristic absorption of Maillard reaction products. Maillard reaction occurs that occur naturally in the ingredients.

Sugar the greatest role in the Maillard reaction is fructose and glucose. Sucrose in sugar levels by $74.68 \%$, $1.9 \%$ fructose and glucose $3: 43 \%$, whereas the free amino acid is lysine, tryptophan, glutamate acid, aspartic acid, alanine and glycine [17]. Lysine amino acid most quickly produce color caused by the $\varepsilon$-amino group is highly reactive. So supposedly the more addition of brown sugar in the fish ketchup processing the higher the degree of Maillard generated.

\subsection{Physical Analysis}

\section{Color}

The level of Lightness (L) was measured using a color reader that has a value ranging from 1-100. Values indicated the greater the level of brightness, the color white. The level of brightness (a) values ranging between 80- $(+100)$ showed a green color to red. While (b) values ranging between $-50-(+70)$ showed a blue color to yellow. The results of the color analysis sauce and fish sauce are shown in Table 2 below.

Table 2. Results of Analysis Color FishSauce and FishKetchup

\begin{tabular}{ccccccc}
\hline Ratio of & \multicolumn{3}{c}{ Fish Ketchup } & \multicolumn{3}{c}{ Fish Sauce } \\
\cline { 2 - 7 } Biduri : Papain & \multicolumn{3}{c}{ Color } & \multicolumn{3}{c}{ Color } \\
\cline { 2 - 7 } (B):(P) & L & a & b & L & a & b \\
\hline 30 B : 70 P & 40,5 & 9,4 & 18,9 & 63,0 & 9,2 & 25,6 \\
50 B : 50 P & 41,1 & 8,9 & 18,2 & 62,8 & 9,1 & 23,2 \\
70 B : 30 P & 41,7 & 7,1 & 17,2 & 63,7 & 8,9 & 22,5 \\
\hline
\end{tabular}

Data were presented as analysis of physical charachteristic using Fardiaz (1994), triplicate $(\mathrm{n}=3)$.

Based on the above data, the addition of enzymes can improve the color of fish ketchup and fish sauce. The addition of additives such as brown sugar with a concentration of $30 \%$ and $10 \%$ in the manufacture of caramel fish sauce andfish ketchup affect the resulting color. In the sauce, the addition of CMC affect the color of fish sauce produced. Besides as emulsifiers and thickeners, CMC can also ensnares particles - particles that can cause a thin layer of dark color resulting from the fish sauce. Allegedly papain enzyme and hydrolysis process will cut the peptides so as to increase the number of amine groups. Amine group reacts with the carboxyl group which caused the Maillard reaction and produce the dark color of the resulting hydrolyzate. Similarly, the ratio of sugar to amino acid affects the color-forming reaction. Increasing the amount of amino acids, the more the formation of color [18]. 


\section{Viscosity}

Viscosity average value of inferior fish sauce produced from a combination of the addition of thickening agents ranged between 14.86 to $18.78 \mathrm{mp}$. While the average viscosity value obtained from the study of fish ketchup and it ranged between $10.81-14.80 \mathrm{mp}$. The observation of inferior fish sauce viscosity can be seen in Figure 5 below:

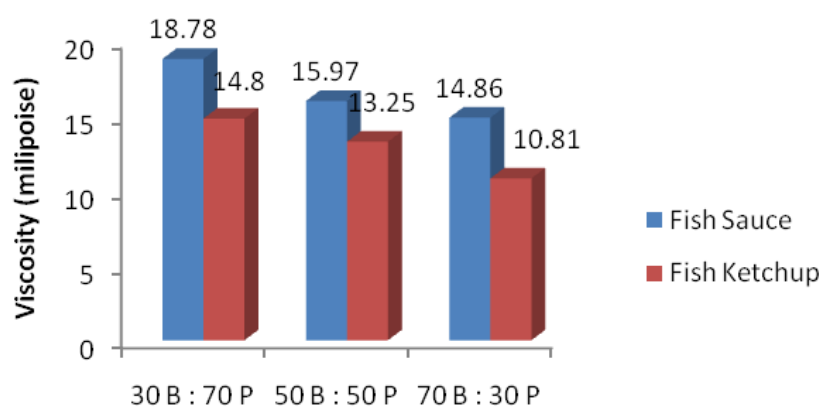

Ratio of Biduri (B) : Papain (P) Enzyme

Figure 5. Viscosity of Fish Sauce and Fish Ketchup

According Suprapti [19], the viscosity of the sauce and ketchup is influenced by two things, the materials used, including the addition of brown sugar and a thickening agent, such as CMC; processing to achieve a certain level of viscosity. The process of warming will increase the dry ingredients in the fish ketchup because the evaporation of water, this will also increase the viscosity of ketchup. Increasing viscosity because proteins found in the spice content will be denatured by the heating so that the solubility will decrease. As stated by Winarno [18] will be reduced solubility of protein denatured.

The viscosity is directly proportional to the concentration of the solution. The more particles are dissolved, the higher the friction between the particles and the higher the viscosity. The addition of sugar will cause the bound water into food. Increasing the concentration of dissolved solids in solution, the lower the Water Activity (Aw) [20]. The addition of sugar also affects the gel formed by the sugar mixed with water will experience melting. Protein and sugar binds water, so as to increase the viscosity of fish ketchup and fish sauce inferior. Viscosity of the solution can also be affected by temperature, pressure, molecular weight, and concentration of the solution and dissolved materials that exist [21].

\subsection{Amino Acid Composition}

The amino acid composition of fish hydrolysate as major product to make fish sauce and ketchup may be nutritionally important especially in regions where it serves as a significant source of dietary protein. The compositions of amino acid from bibisan fish hydrolysate were shown in Table 3.

The highest amino acid in bibisan fish hydrolysate was glutamic acid that range from $8,76 \%-10,17 \%$; while the lowest AA was Histidine (1,12-1,22\%). Eight essential amino acids were identified among the total content of amino acids of fish hydrolysate, including threonin, tyrosine, methionine, valin, phenylalanine, i-leucine, leucin, and lysine. The predominant AAs amongst the non essential amino acids were glutamic acid and aspartic acid, and those amongst the essential amino acids (EAAs) were lysine and leucine. Glutamic acid had important roles as flavor-enhancing compounds which provide an umami (savory) taste in food. Lysine, which is severely restricted in cereals, the most important staple food in the world. A reduced supply of lysine in the diet may lead to mental and physical handicaps because it is an important precursor for the novo synthesis of glutamate, the most significant neurotransmitter in the mammalian central nervous system [22] (Papes et al., 2001). The essential amino acids requirement for adult man weighing $70 \mathrm{~kg}$ is about $5.59 \mathrm{~g}$ per day [23]. The results indicated that $100 \mathrm{~g}$ of all the study fishes, met the daily requirement for essential amino acids.

Tabel 3. Compositions of Amino Acid From Bibisan Fish Hydrolysate

\begin{tabular}{lccc}
\hline \multirow{2}{*}{ Amino acid } & \multicolumn{3}{c}{ Results $(\% \mathrm{~b} / \mathrm{b})$} \\
\cline { 2 - 4 } Aspartic Acid & $30 \mathrm{~B}: 70 \mathrm{P}$ & $50 \mathrm{~B}: 50 \mathrm{P}$ & $70 \mathrm{~B}: 30 \mathrm{P}$ \\
Glutamic Acid & 6,12 & 5,94 & 5,13 \\
Serine & 10,17 & 8,76 & 8,76 \\
Histidine & 2,49 & 2,50 & 2,60 \\
Glycine & 1,12 & 1,14 & 1,22 \\
Threonin & 2,68 & 2,80 & 2,35 \\
Arginine & 3,133 & 3,14 & 2,85 \\
Alanine & 4,11 & 4,08 & 3,88 \\
Tyrosine & 3,51 & 3,44 & 3,51 \\
Methionine & 2,13 & 2,25 & 2,20 \\
Valine & 1,92 & 1,98 & 1,98 \\
Phenylalanine & 2,92 & 2,93 & 3,01 \\
i-leucine & 2,53 & 2,54 & 2,58 \\
Leucine & 2,75 & 2,91 & 2,86 \\
Lysine & 4,95 & 4,96 & 4,76 \\
Total AA & 5,44 & 5,67 & 5,90 \\
\hline
\end{tabular}

Note: $\mathrm{B}=$ Biduri Enzyme; $\mathrm{P}=$ Papain Enzyme

\subsection{Sensory Analysis}

Organoleptic characteristic testing the testers tend to make judgments based on favorite. Organoleptic testing fishketchup and fish sauce made in the 25 panelists who include organoleptic test the taste, aroma and color. Panelists were asked to provide an assessment of the favorite fish ketchup and fish sauce compared with fish sauce and ketchup on the market as a control. The results of sensory analysisincluding the taste, aroma, and color of fish ketchup and fish sauce are presented in Table 4.

Table 4. Sensory analysis scores of fishketchup and fish sauce from bibisan fish hydrolyzate

\begin{tabular}{ccccc}
\hline \multirow{2}{*}{ Sample } & \multicolumn{4}{c}{ Ranking Average } \\
\cline { 2 - 5 } & Taste & Aroma & Color & Texture \\
\hline Control of ketchup & $2,2^{\mathrm{a}}$ & $1,84^{\mathrm{a}}$ & $2,08^{\mathrm{a}}$ & $1,8^{\mathrm{a}}$ \\
Fish ketchup & & & & \\
1. 30B:70P & $2,52^{\mathrm{a}}$ & $2,96^{\mathrm{b}}$ & $3,44^{\mathrm{b}}$ & $3,36^{\mathrm{bc}}$ \\
2. 50B:50P & $2,48^{\mathrm{a}}$ & $3,04^{\mathrm{b}}$ & $3,6^{\mathrm{b}}$ & $3,84^{\mathrm{c}}$ \\
3. 70B:30P & $2,52^{\mathrm{a}}$ & $3,36^{\mathrm{b}}$ & $3,56^{\mathrm{b}}$ & $2,96^{\mathrm{b}}$ \\
Control of sauce & $2,6^{\mathrm{a}}$ & $3,04^{\mathrm{a}}$ & $3,04^{\mathrm{a}}$ & $3^{\mathrm{a}}$ \\
Fish sauce & & & & \\
1. 30B:70P & $2,24^{\mathrm{a}}$ & $2,52^{\mathrm{ab}}$ & $2,84^{\mathrm{a}}$ & $3,36^{\mathrm{a}}$ \\
2. 50B:50P & $2,36^{\mathrm{a}}$ & $2,28^{\mathrm{b}}$ & $3,28^{\mathrm{a}}$ & $3,36^{\mathrm{a}}$ \\
3. 70B:30P & $2,48^{\mathrm{a}}$ & $2,44^{\mathrm{b}}$ & $2,92^{\mathrm{a}}$ & $3,16^{\mathrm{a}}$ \\
\hline Remarks: Figures followed different letters in the same column indicate
\end{tabular}

Remarks: Figures followed different letters in the same column indicate significant differences $(\alpha=0.05)$. Score 5 (highly preferred) to a score of 1 (not preferred). 
The sensory attributes evaluated of fish sauce and ketchup reveals that the products have a good sensory quality and overall acceptability. Though the products were found to have good taste (2.24 to 2.6), aroma (2.28 to 3.36), color (2.84 to 3.6), and texture (2.84 - 3, 84). Taste of fish ketchup and fish sauce has a flavor that is preferred than the control, but not significantly different (Table 4). That means fish ketchup and fish sauce has a flavor that is equivalent to the level of control. Factors that affect the quality of flavor that processing of fish into the fish hydrolyzate using a combination of Biduri protease and papain. Amino acids found in many fish hydrolyzate is glutamic acid that had important roles as flavorenhancing compounds roomates provide an umami (savory) taste in food [22]. Specific flavor of fis ketchup and fish sauce are also determined by the type of spices used and the addition of brown sugar, so that the composition of different spices will give a different flavor as well.

Fish ketchup has a scent that is preferable to control and fish sauce. Fish ketchup aroma significantly different tocontrols. While the fish sauce, the sauce is preferred over control of bibisan fish hydrolyzate. The complex interaction of enzymatic activity between Biduri protease and papain can produce volatile fatty acids may be responsible for flavor and aroma charachteristic of fish hydrolyzate [24].

Color of fish sauce and ketchup were significantly different tocontrol. This shows, the color of the fish sauce and fish ketchup frombibisan fish hydrolyzate be preferable because color of fish sauce more bright than control (light brown). Neither the color of fish ketchup, preferable to control due to solid black. Color occurs because the browning reaction between an amino acid with a reducing sugar [25]. Color is very important becausesincethe fish ketchup is closely connected with the resulting flavor. The addition of brown sugar and caramel cause brown color and the increasing of viscosity which is the specific nature of traditional fish ketchup.

\section{Conclusion}

Fish sauce and ketchup with acceptable quality may be produced from bibisan fish hydrolyzate. Making fish ketchup and fish sauce from the bibisan hydrolyzate can shorten production time. This is because it does not require fermentation as in the manufacture of fish sauce and fish ketchup in general. Production of bibisan fish hydrolyzate also does not require a long time because it uses a combination of Biduri and papain enzyme. The overall acceptability of charachteristic and sensory evaluation of fish sauce and ketchup both graded as acceptable for consumption.

\section{Acknowledgments}

We would like to thanks to the Directorate of Higher Education, Ministry of Education and Culture, Republic of Indonesia through the Research Grant for providing financial support to carryout this project.

\section{References}

[1] Kunst, A., "Enzymatic Modification of Soy Proteins to Improve Their Functional Properties. Magazine of Industrial Proteins”, 8 (3), 9-11. 2000.

[2] Witono, Y., "Isolation and Characterization of a Protease Enzyme Plant sap Biduri. J. Agricultural Technology, 1 (1), 1- 14. 2002a.

[3] Witono, Y.,“Utilization of Plant Protease Enzyme for Food Processing Biduri. J. Science and Technology, 1 (1), 32-37. 2002b.

[4] Witono, Y., Aulanni'am, Subagio, A. and Widjanarko, SB., “Study of Protease Production Technology Directly from Plant Biduri. Journal of Agro Technology, 1 (1). 2007a.

[5] Witono, Y., Aulanni'am, Subagio, A. and Widjanarko, SB., "Purification and Partial Characterization of a Protease Enzyme Plant Biduri. Journal of Technology \& Food Industry, 18 (1), 1-9. 2007b.

[6] Witono, Y., Zamroni, I. and Windrati, W.S., "Old Water Interaction Research Introduction and Results Hydrolysis of "Kuwe“ Fish. Seminar Papers, Jember, Indonesia. 2011.

[7] Gustaf Helgi Hjalmarsson, Jae W. Park, Stuelzis Kristbergsson, "Seasonal effects on the physicochemical characteristics of fish sauce made from capelin (Mallotus villosus)”. Elsevier, Food Chemistry 103 (2), 495-504. 2007.

[8] Fukami K, Satomi M, Funatsu Y, Kawasaki K, Watabe S, "Characterization and distribution of Staphylococcus sp. Implicated for improvement of fish sauce odor”. Fish Science 70 (3), 916-923. 2004.

[9] AOAC, “Official Methods of Analysis 16th edition. Association of Official Analytical International”. Maryland. USA. 2005.

[10] Sudarmadji, S., B. Haryono and Suhardi.,"Procedures for the Analysis of Food and Agriculture”. Yogyakarta, Liberty, Indonesia. 2007.

[11] Hofmann T, Bors W, dan Stettmaier K., "Studies on Radical Intermidiates in the Early Stage of the Nonenzymatic Browning Reaction of Carbohydrates and Amino Acids”, J. Agric. Food Chem, 47: 379-390. 1999.

[12] Lawless, H.T. and H. Heymann, "Sensory Evaluation of Food, Principles and Practices”. (pp.827). Aspen Publishers. Gaitherburg, MD. 1998.

[13] Bragado' ttir, M., Palmado' ttir, H., \& Kristbergsson, K, “Seasonal changes in chemical composition and quality parameters in capelin (Mallotus villosus)”. Journal of Aquatic Food Products and Technology, 11 (3), 87-104. 2002

[14] Bersamin, SV, \& Napugan, RSJ, "Preliminary comparative studies on the chemical composition of the different commercial brands of Patis in the Philippines”. Philippines Journal of Fish, 151-157. 1961

[15] Lopetcharat, K., Choi, YJ, Park, JW, \& Daeschel, MD, "Fish sauce products and manufacturing - a review”. Food reviews International, 17 (1), 65-88. 2001

[16] Sari LE,"Effect of Combination of Materials Alginate stabilizer, Carragenan, and CMC Against Character Quality Ice Cream ". Jakarta: Study Program of Chemistry, Faculty of Science and Technology, Islamic State University Syarif Hidayatullah. 2008.

[17] Jayalekshmy and Methew, "Changes in the carbohydrates and proteins of coconut during roasting”. Food Chemistry 37: 123-134. 1990.

[18] Winarno, F. G, “Food Enzymes”. Jakarta: PT Gramedia. 1995.

[19] Suprapti, L, "Ketchup coconut water. Issue of food processing technology”. London: Canisius. 2005.

[20] Buckle, K.A., R.A. Edwards, G.H. Fleet, and M. Wooton, "Food Sciences”. Jakarta: Indonesian University Press (pp. 365). 1987.

[21] DeMan J, "Principles of Food Chemistry”, 3rd ed., Springer. 2007.

[22] Papes, F., Surpili, JS, Langone, F., Trigo, JR, \& Arruda, P, “The essential amino acid lysine acts as precursor of glutamate in the mammalian central nervous system”. FEBS Letters, 488 (2), 34-38. 2001

[23] Gawedzki, J., (ed) "Bialka zywnos ci $\quad$ w $\quad$ w Poznaniu zywieniu.Wyd.AkademiiRolniczej i_. Poznan”. 1997.

[24] Beddows, C.G., ArdeshirA.G. \& David, W.J., "Development and Origin of Volatile Fatty Acids in Budu”.J Sci Food Agric, 31 (3), 86-92. 1980

[25] Astawan, M and M.W. Astawan, "Vegetable Food Processing Technology Appropriate”. 1 edition New York: Academic Pressindo. 1991. 